\title{
Parasocial Interaction Among Young Female Devotees of Korean Dramas
}

\author{
Bernadeta Meidy Setya Putri and Danny Irawan Yatim \\ Faculty of Psychology \\ Universitas Katolik Indonesia Atma Jaya
}

\begin{abstract}
Korean drama is a media broadcast, which provides interactive parasocial experience to its enthusiasts, who actively seek out and involve themselves in it. The interactive parasocial process is divided into cognitive, affective, and behavioral sub-processes, producing "imagined interaction". These shows have both positive and negative impacts upon their devotees; however, the way in which the parasocial interaction for the devotees of Korean dramas comes about is not yet well understood. A picture of this parasocial interaction for four young adult female devotees was obtained through interviews and journal entries. The participants used characters in Korean dramas as role models, and as parts of a learning process in their life transitions. They also used them as facilities for having social contacts, lessons about romantic relationships, and future career perspectives. Thematic analysis of this parasocial interaction produced a number of themes, these being the function of Korean dramas in the lives of devotees, "binge watching" as a recurrent parasocial interaction, and imaginings as romantic experiences. This research revealed that the cognitive sub-processes had a large part to play in the progress of parasocial interaction. It is recommended that further research be conducted into the impact of Korean dramas, as media products, upon Indonesian society.
\end{abstract}

Keywords: parasocial interaction, Korean dramas, young adult women

Drama Korea merupakan paparan media yang memberikan pengalaman interaksi parasosial kepada para penggemar yang secara aktif mencari dan melibatkan diri dalam pemaparannya. Proses interaksi parasosial terbagi terbagi menjadi subproses kognitif, afektif dan perilaku yang menghasilkan imagined interaction. Pemaparan tersebut memberikan dampak positif maupun negatif pada kehidupan penggemarnya, namun bagaimana terjadinya interaksi parasosial pada penggemar drama Korea ini belum banyak diketahui. Gambaran interaksi parasosial empat perempuan dewasa muda penggemar drama Korea diperoleh melalui wawancara dan penulisan jurnal. Partisipan menggunakan tokoh dalam drama Korea sebagai model dan pembelajaran dalam transisi hidup mereka. Partisipan juga menggunakan drama Korea sebagai sarana bersosialisasi, pembelajaran hubungan romantis dan pandangan karir masa depan. Analisa tematik terhadap interaksi parasosial menghasilkan beberapa tema, yaitu fungsi drama Korea dalam kehidupan penggemar, binge watching sebagai proses interaksi parasosial berulang, dan imajinasi sebagai pengalaman romantis. Penelitian ini menemukan bahwa subproses kognitif memiliki porsi besar dalam jalannya interaksi parasosial. Disarankan penelitian lanjutan mengenai dampak drama Korea sebagai produk media terhadap budaya Indonesia.

Kata kunci: interaksi parasosial, drama Korea, perempuan dewasa muda

Korean dramas are media broadcasts, which have many devotees in Indonesia. There has been significant increase in the demand for Korean broadcasts, which come from the international providers, iFlix and Viu (Khoiri, 2018). Variations in broadcasts are growing, beginning with the content, through to the

Correspondence concerning this article should be addressed to Bernadeta Meidy Setya Putri, Faculty of Psychology, Universitas Katolik Indonesia Atma Jaya. Jalan Jenderal Sudirman 51, Jakarta Selatan 12930, Indonesia. E-mail: bernadetameidy@gmail.com technology used in obtaining the images, with the aim of providing the maximum enjoyment to viewers. Korean dramas themselves have their strengths in story packaging and playing on the emotions of viewers.

According to Jung (as cited in Chuang \& Lee, 2013), Korean drama themes are familiar to the lives of viewers, and so give rise to enjoyment in following a broadcast. The viewers of Korean dramas have a desire to seek certain feelings, such as love, anger, and sadness, when enjoying them. The dramas categorized 
as being successful are those able to drain the emotions of viewers (Chuang \& Lee, 2013). The behavior of viewers of Korean dramas also influences the devotees in matters of food selection, styles of dressing, knowledge of Korean culture, and ways of viewing Korean citizens (Jeong, Lee, \& Lee, 2017). The process of imitating the characters in these dramas is a response in the form of parasocial interaction (Giles, 2002). The characters in the dramas display personalities which the viewers wish to display, rather than displaying their own natural personalities. These are called personas (Brown, 2015). For this reason, the information gained by viewers regarding these personas is processed on the basis of viewer subjectivity. Parasocial interaction is a mono-directional response, made by the viewers of these media shows (Giles, 2002). Parasocial interaction can occur with all forms of media, and can develop to become parasocial relationships, and are always mono-directional in nature.

Korean dramas are included in the classification of "soap opera", and are more enjoyed by female viewers (Geraghty \& Weissmann, 2016), so that parasocial interaction with Korean dramas is also more prevalent with women. Cohen (as cited in Lather \& Moyer-Guse, 2011) stated that women experience stronger parasocial relationships with the characters of the dramas more easily. Women can see themselves in drama serial broadcasts, and use these drama serials as an indirect means of escaping negativity (Goodwin \& Whannel, as cited in Bryant \& Zillmann, 2002). Ahmed and Khalid (2012) stated that serial dramas have the material to end problems, making women feel supported. Korean dramas themselves are preferred by young adult women, because they often contain stories of the lives of young women.

People who are unable to differentiate between illusion and reality, will develop obsessions in their personas. Horton and Wohl (as cited in Syafrina, Permatasari, \& Dara, 2016) stated that pathological parasocial relationships develop when the person concerned makes such a relationship an alternative to social participation in real relationships. This pathological situation is also indicated when parasocial relationships develop into worship of celebrities (celebrity worship), the emergence of feelings that the persona is hiding - similar to feelings of love (crotomania), and to subsequent stalking-like behavior (Horton \& Wohl, as cited in Syafrina, Permatasari, \& Dara, 2016). The relationship between the devotee and the idolized character is seen as dysfunctional, because many people allow themselves to maintain illusional/illusionary rela- tionships rather than develop real relationships with others (Stever, 2011a).

Parasocial interaction proceeds like other social interactions, such as when a person imagines an interaction will occur between him or herself and someone else (Madison \& Porter, 2016). The interaction occurs in his or her imagination, and not in real life. Parasocial interactions appear to be occurring in real life, but actually it is the imagination which has a role in the process. The imaginings formed from this parasocial interaction gives the impression that a person has performed an interaction with the character.

Adam and Sizemore (2013) stated that a parasocial interaction can cause a person to not need a real experience to be able to learn something. For example, a parasocial interaction which develops into "parasocial romance" causes a person to be able to feel love, without having to fear heartbreak (Adam \& Sizemore, 2013). The imagination that they have fallen in love causes a person to experience "parasocial romance". The love given by the fictional character, and the feelings this gives, do not come from actual experience.

This mono-directional parasocial characteristic is very dependent upon the significance attributed by the individual. On the basis of "symbolic interactionism", the behavior of the person is based upon their understanding of a matter (Blumer, as cited in Tsay-Vogel \& Schwartz, 2014). This understanding is produced based upon the social interaction which occurs. Understanding is an interpretive process, between a person and an object. As an example, Vorderer and Knobloch (as cited in Klimmt, Hartmann, \& Schramm, 2006) stated that parasocial interactions are greater for a shy person, who has a greater need for social interaction. A shy person needs social interaction, just as does an ordinary individual, but has difficulties in initiating interaction with an actual person, so parasocial interaction with a character in a drama is more beneficial.

This research was aimed at illustrating the parasocial interaction occurring for devotees of Korean dramas. The Korean dramas enjoyed have an impact upon a person, which not infrequently develops to become a real necessity. People who experience parasocial interactions also do not yet actually realize the effects of the process upon them, until they are too deeply involved in the broadcasts. The apparent response from the Korean drama devotees is to manifest similar emotional characteristics, which are produced through the parasocial interaction of the viewers with the characters in the shows being watched. Therefore, the process which occurs with people who experience 
these Korean dramas needs to be thoroughly understood.

\section{Method}

The method employed was phenomenological approach, with the aim of looking at the parasocial interaction of devotees of Korean dramas. This approach was selected to illustrate the daily life experiences in more depth. This approach also made possible the emergence of awareness of one occurrence, and the discovery of several important matters (Patton, 2001). Qualitative interviews using open questioning were conducted, to extract information (Yin, 2011).

Qualitative data extraction was also conducted in this research through the writing of journals. Journal entries were used by the researchers to reduce bias and maintain the neutrality of the researchers in the analysis of the results of the interviews. A journal can give a view of the daily life of participants (Bolger, Davis, $\&$ Ravaeli, 2003). The writing of journals was used as a research method as well as an interpersonal process. Journal writing had the function of capturing the subjective values of the participants, which had not emerged in the interviews. The journal writing also assisted the researchers in knowing the daily lives of the participants (Kaun, 2010).

The participants were requested to write their journals as a matter of routine, after watching the Korean dramas.

The characteristics of the participants were: (1) female, between the ages of 18 and 25 years; (2) devotees of Korean dramas; (3) active seekers of Korean dramas to watch; (4) had watched more than five drama series in the past year (a Korean drama continues for around three months, so that in one year there are at least four new dramas available for viewing); and (5) were routinely watching Korean dramas.

Examples of the questions asked are: "How did you begin watching Korean dramas?"; "For how long do you watch a Korean drama?"; "What thoughts emerge when you are watching (title of drama)?"; "How do you feel when you are watching Korean dramas?"; and "What response (behavior) normally manifests itself when you are watching Korean dramas?".

There were four participants in the research: ES, YR, JY and WD. These initials are used to protect the secrecy of the identity of the participants. The research used "thematic analysis" to identify themes, patterns, and unique findings, amongst the participants (Braun \& Clarke, 2006).

\section{Results}

\section{Parasocial Interaction}

The devotees of Korean dramas are characteristically active in searching for information concerning the newest dramas. With the four participants, it was found that they all renewed their viewing, as could be seen from their journals. It can therefore be concluded that participants were continuing to watch the dramas still being broadcast on Korean television. The first participant, ES, preferred Korean dramas with an "office romance" theme, because the emergence of professional relationships turned ES's imagination to the world of the office and a career, and this in Korea was shown in detail. YR liked romantic and family themes, when YR watched dramas. JY and WD particularly liked romantic themes.

YR and ES stated that Korean dramas gave a more detailed and better illustration of life. The provision of very detailed depictions made the viewers feel as if they were in the situation of the drama. In contrast to the broadcasts of Western dramas, Korean dramas presented a reality full of fantasy. Though this was so, real information was also able to be displayed in an interesting fashion. The four participants also said that the players in the Korean dramas, both male and female, had attractive faces, which gave the Korean dramas a degree of visual attraction.

Appearances as shown in Korean dramas influenced the cognitive and affective sub-processes, as well the behavior of the participants, when they were experiencing parasocial interactions. JY would scream hysterically from frustration, when the television screen showed the male lead talking to his female opposite number. This response was manifested because the stimulus provided by the Korean dramas was able to provide an experience which appeared to be real, in the minds of the viewers. The pleasurable experience provided by the Korean dramas caused the participants to strive to enjoy the shows free of distractions, and in comfort. They wished to undergo their viewing experiences complete with the sensations provided by these Korean dramas. They chose to enjoy the dramas in solitude, so as to be more focused. The efforts made by the participants to ensure this focus caused the interaction between programme and viewer take place in a more intense fashion, even though it was merely a parasocial interaction.

The cognitive sub-processes were filled with the information displayed in the Korean dramas. "Attention allocation" took place when the participants watched 
the first episode of a drama. Information about the drama, the story plot and characterization, were formed when the participants first viewed the drama shown. "Attention allocation" was displayed when the participants understood the focus which they had determined in viewing the drama, such as the main characters and the story line. The cognitive sub-processes involved the knowledge of and apparent situations of the participants. Therefore, the finding that each participant had their own view of the drama being viewed could be made.

YR and JY, who watched the same drama, "Something in the Rain", certainly had differences in their information processing. YR saw the father in the drama as a caring figure, able to understand his children, whilst JY was more of the view that the female was the eternal key to a romantic relationship. This difference in focus was also subject to the influence of the age of the participant. JY was 21 years old, and had completed her university studies, whilst YR had only just entered the world of tertiary education. This aside, YR also had an interest in family-themed stories.

Cognitive sub-processes which involve "self-related feelings", such as the "construction of relations between self and persona", produced a response which was then manifested in the affective sub-processes. YR, who had experienced sadness because YR liked someone who liked someone else, felt the sadness of the character Jung Pal, in the drama "Reply 1988". The information about Jung Pal, which was presented in the drama, was processed via the cognitive sub-processes and produced feelings in the participant which portrayed the feelings of the character. This also occurred with JY having experienced the situation of the character Jin Ah, being in a relationship with a younger man. This similarity caused JY to be able to capture the emotions displayed by the character Jin Ah, in the drama "Something in the Rain".

The researchers observed that the cognitive sub-processes functioned in every viewing activity of the participants. The researchers also saw no differences in these sub-processes between those involved in a drama which had been viewed a long time previously, and those for the dramas written about in the journals. The results of these sub-processes normally became the reasons for their interest in viewing later episodes of the drama. The cognitive sub-processes were a source of data which produced the responses, such as those affective and behavioral.

In the affective sub-processes, "emphatic reaction" was often observable with the dramas being viewed. YR, JY and WD had favorite dramas, so that they de- scribed in more details the feelings in those dramas; however ES, who preferred dramas of the "office romance" genre, appeared more enthusiastic when describing the emotions, in the drama which ES was currently watching. Based upon the affective sub-processes experienced by the participants, it may be seen that emotional experiences remain, even when the participant is not viewing, and are stronger when the viewing experience has just recently commenced.

"Mood" shifts in the affective sub-processes are more dominated by negative "moods". The four participants saw the Korean dramas as presentations which could arouse immediate feelings of sadness, such as those in the sad dramas they watched, in their viewers. However, when they demonstrated other "moods", such as falling in love, the researchers observed that feelings of falling in love were often manifested by participants, although they tended to produce these responses through behavioral sub-processes.

Regarding behavioral sub-processes, the four participants demonstrated similar responses when watching Korean dramas. ES cursed at unexpected scenes. YR often shouted when watching. JY commented on the behavior of characters, as if in an argument. With $\mathrm{WD}$, behavioral the responses shown were in the form of smiles, and angry expressions. The researchers noted that WD preferred to conceal her visible behavioral responses, i.e., by mimicking facial expressions and bodily movements.

The results of the parasocial interactions experienced by the participants offered lessons which are used in everyday life. JY, who confessed to being an awkward person, used Korean dramas to study male behavior. YR used Korean drama as conversation material, when talking to people YS did not know. ES made Korean drama the realization of ES's imagination, and also, indirectly, to form a depiction of romantic relationships. WD used Korean drama fully as entertainment, and cultural learning, such as in regard to language and lifestyle.

The process of parasocial interaction began the first time the participants viewed Korean dramas, and continued through to them becoming devotees. The four participants stated that Korean dramas had "colored" their lives. Korean dramas had the function of raising their "moods" and keeping them continuously consoled in their lives, which were felt to be fully dynamic. For that reason, the process which they experienced when viewing was explained as an entertainment activity, important for their lives.

"Korean dramas are entertainment (laughs)... Enter- 
tainment which colors my life. Korean dramas can possibly, can also sometimes be escapist, eh? (You think suddenly, that just now was entertainment, wasn't it, then suddenly you think it was escapist too, sometimes. What does that mean?) Well, because when I am, I don't know, sad, disappointed, totally bored, after that I watch happy Korean dramas, and, well, I become happy as well." (ES, 21 years old)

The four participants also had the habit of watching more than one episode at a time. On the basis of the findings of Exelmans and Van De Bulck (2017), the behavior of watching a number of episodes at one sitting is construed as being "binge watching". Thus, it can be determined that the participants indulge in "binge watching". Regarding YR's viewing activity, YR could be observed repeatedly watching previously viewed dramas. Those "binge watching" activities had negative effect on YR's health, such as with YR drinking three glasses of coffee daily, to keep alert when viewing the dramas. YR was unconcerned with YR's responsibilities as a student, continuing to watch during examination times. YR was aware of the negative impact, but did not know why YR was unable to cease this habit.

"Binge watching" also occurred with ES, JY and WD. Based upon their description of their activities whilst watching, ES and JY were able to determine appropriate times for watching, without disrupting the performance of their responsibilities. JY was able to postpone watching the dramas when faced with sitting for the national examinations. This postponement of JY's watching activities was later on compensated for, by "binge watching" the dramas JY had previously prepared. "Binge watching" was most prevalent during the holiday period, when participants had no responsibilities to meet. YR and JY preferred watching Korean dramas all day long, to going out or the house. Watching was no longer entertainment, but had become a need for the participants.

The parasocial interaction which they experienced whilst viewing Korean dramas caused the participants to want to repeat the experience. Because of this, they repeated or increased their watching, so as to continue the feeling gained. "Binge watching" can be described as the repetition of the experience of parasocial interaction. With each episode viewed, they gained a different parasocial interaction. These differences provided new watching experiences, and increased their desires to continue watching.

For YR, the repetition of, and the additional, view- ing of Korean dramas increased the affective responses. YR felt that Korean dramas were able to give YR experiences unavailable in the real world. The importance of Korean dramas for the participants made them watch them continually, until they were "binge watching".

"How can I put it? I can laugh. I can cry. I'm like a romance junky, something like that, yeah? It's like I am addicted to romance films. So it's like I'm getting what I want to watch, and in my daily life I don't get any romance. By watching continuously, I can keep on getting those feelings." (YR, 19 years old)

\section{Imagined Interaction}

The four participants were single women, each of whom had her respective ideal criteria for a partner. ES, who liked "office romance" genre dramas, had imaginings of romantic relationships in the workplace, or in a particular profession. These imaginings were actually formed from the preferences of ES, who wanted a quality professional relationship when ES met someone of the opposite sex. By viewing Korean dramas, ES felt her imaginings had come to fruition, without ES having to give form to them in real life.

Differently to ES, YR allowed YR's imagination to run like the plot of a drama, and imagined YR falling in love with the male lead, and responding to the situations which were offered up in the drama. Korean dramas also formed the participants views of the physical ideals of a male partner. ES imagined ES's self as slim as the female lead in the drama, and to have a partner as handsome as the Korean actor.

Imagining having a Korean actor as partner also occurred with WD. WD said honestly that WD would be very pleased if WD's idol, Suho, were to come to Indonesia. WD would do anything to get close to Suho. WD imagined Suho as someone whom WD could meet, "chat" to, and communicate with, like a normal friend.

JY used Korean dramas in JY's real life as training to respond to the behavior of male colleagues who approached JY. JY's parasocial character arose when JY re-enacted scenes from in the dramas, and watched JY's self acting these out in the mirror. JY also admitted that JY had an active imagination, often thinking of their self in situations like those in the dramas.

These Korean dramas which have emerged are dominated by romantic themes, but there are also combinations of other themes, i.e., having family, and also work, backgrounds. Even so, the romantic theme is the one having the greatest significance in them. The themes indicated by the participants are also not free 
of romantic life, both real and dramatic. This shows that romantic themes are significant for the participants.

The imaginings of the participants take the form of hopes for romantic experiences which might happen to them. The images of handsome, caring, clever, charismatic, loving, and romantic partners are what is offered by Korean dramas to the participants. The four participants realize that these images are too perfect for a male, but, nonetheless, they enjoy them in their cognitive processes. The images of romantic experience give them happiness, as they might experience in real life.

The awareness of the participants and their imaginings from the Korean dramas caused them to make compromises with reality. The participants pictured the men in the Korean dramas as "the whole package" of the character of an ideal partner. The existence of the compromise made them negotiate with the hopes of having characteristics of a male character from the Korean dramas in their own partners. This indicates that they indirectly wish for a partner in line with the image of males in Korean dramas, and this image of a male is considered to be able to provide romantic experiences as are seen in the dramas.

"A Korean drama gives you the "whole package", doesn't it? Really handsome face. Plenty of money. Really kind. A developing career. Like that. Like a perfect human being. Even if he's arrogant... his arrogance makes you... He's crazy!! Really handsome!! Really cool. The arrogance is the same as coolness. That's a Korean drama, isn't it? Whilst in real life it's not like that, is it? It's not like that. I realize that you will never find that. If you can find one who can discuss things, or can like to be asked to talk, normally... his face...isn't good to look at ... Or his face is good looking but you can't get him to talk about things. So I am aware of that... not aware, but that's what I think." (ES, 21 years old)

\section{Symbolic Interactionism}

The participants reached their own understanding of each drama they watched, such as, for instance, seeing the romantic lives of the characters in the dramas as being learning material for what they had never had in their own romantic lives, as single women. This was influenced by the way the participants lived their social lives, meeting people and building romantic relationships with the opposite sex.

The appearance of women in Korean dramas indicates that, to get a partner, a woman has to be beauti- ful, slim and light-skinned. This view was justified by the participants when they thought that this was what caused them not to have partners, because they did not fulfill these criteria; a view reinforced by the growing popularity of beautiful players in Korean dramas.

As women, the participants saw themselves in the roles of the women in the Korean dramas. They wished to become like the characters in the dramas, with attitudes suitable for those characters. If these Korean drama devotees were startled, they tended to call out utterances in Korean, which they had learned through watching the dramas. These responses were seen as efforts to disguise themselves as the characters in the dramas. On the other hand, people who were not devotees of Korean dramas were not familiar with such utterances. These increasingly popular Korean utterances also made people respond with the same Korean utterances as those made by other devotees. Although this was the case, the meanings of these responses were certainly not identical.

Participants in this research had the habit of watching to excess. The number of dramas watched grew, as time went on. The information received was also increasingly at variance. The participants also were able to experience changes in their tastes, making them not like a number of types of Korean drama. This indicated that the interaction between devotees and programmes could change, based upon the internal situations of the devotees. The participants could change their programmes when they felt that the plots were not in line with their expectations.

On the whole, the participants conceived of the Korean dramas as entertainment which provided learning material. The Korean dramas could become a medium for expressing emotions. The participants had the need to watch Korean dramas as a way of regulating their emotions, as not all of the situations in the drama could occur in real life. Therefore, devotees of Korean dramas always watched these dramas to fulfill needs for this type of entertainment.

\section{Discussion}

Parasocial interaction involves the original evaluation by an individual of a media show (Giles, 2002). Rubin and McHugh (as cited in Giles, 2002) stated that this evaluation commenced when the individual first watches the programme. The first experience of the participant viewing a Korean drama determines their future watching behavior. An impressive watching experience makes the individual wish to continue 
to watch the programme, particularly if it is in serial form. "Symbolic interactionism" is the explanation for the parasocial interaction, which is different for each person. This is because of the difference in interpretation produces a different response, and the response also alters subsequent interpretations.

Rubin and McHugh (as cited in Giles, 2002) stated that the interpretation of the viewer is influenced by the physical appearance, duties and social description of the persona. This research also indicates this finding. Information from others concerning a programme also influences a participant in choosing the dramas viewed. Thus, external information and the attraction for the individual may be of mutual influence in the selection of a programme.

Klimmt, Hartmann, and Schramm (2006) stated that the cognitive process can support the occurrence of the affective and behavioral processes. In the viewing experiences, it was observed that the cognitive processes of the participants was an important matter, and became the basis for other responses. The way the participants processed the information presented produced perceptions of the programme which elicited responses. The processing of information happened in the cognitive processes, principally when the participants attempted to connect one matter with another, in their lives and in the dramas viewed.

"Transportation" and parasocial interaction are illustrations of the involvement of the participants in the broadcasts (Brown, 2015). The male characters in the drama became "sparring partners" in the imagination of the individuals. The participants created scenarios and imaginings on the basis of fictional stories. Fiction, which offers stories with a wide range of emotions, encouraged the participants to involve themselves in these stories. "Transportation" is a situation in which a person enters into a story plot (Green \& Dill, 2013). This situation occurs because of the presence of strong parasocial interaction, throughout the viewing behavior of the individual.

Giles (2002) attempted to see parasocial interaction proceeding appropriately for someone responding to a person with whom they were having a discussion. Rubin and Perse (as cited in Giles, 2002) argued that parasocial interaction takes place on the basis of the human instinct to build relationships with others. This was also indicated by the participants, when they saw parasocial interaction as visualization, learning material, and also a method of socializing. Vorderer and Knobloch (as cited in Klimmt, Hartmann, \& Schramm, 2006) stated that parasocial interaction was greater amongst shy individuals, who have a great need for so- cial interaction.

There is, as yet, no integrated theory of the concept of parasocial interaction, making research into parasocial interaction a challenge (Klimmt, Hartmann, \& Schramm, 2006). For this reason, the use of the concept of parasocial interaction focuses upon how individuals grasp and processe media programmes (Klimmt, Hartmann, \& Schramm, 2006). This research attempted to illustrate parasocial interaction from the initial introductory viewing of a programme to the emergence of the significance of Korean dramas in the lives of devotees. In the process which takes place, there is a dynamic, from when the individual really likes a character, until feelings of disliking the programme. Even so, the person still intensely enjoys Korean dramas. This type of programme, i.e., a serial drama, is an entertainment need for the participant, wherein viewing becomes a necessity. Parasocial interaction, as entertainment experience, contains a process which may produce "enjoyment" (Zilmann, as cited in Klimmt, Hartmann \& Schramm, 2006) and identification (Cohen, as cited in Klimmt, Hartmann \& Schramm, 2006) within the viewer.

Viewing Korean dramas was a pleasing activity for their devotees. This feeling of happiness was produced by their parasocial interaction. Devotees of Korean dramas displayed a tendency to involve themselves in seeking, and adding to, knowledge of their idols (Chin \& Morimoto, 2013). Efforts always to be close to their idols lead to devotees indulging in "binge watching".

The viewing of Korean dramas as an entertainment also increased the enthusiasm of the participants. They indulged in "mood management", and this may explain why people enjoy such drama programmes. According to Zillmann (as cited in Bartsch \& Viegoff, 2010), people choose broadcasts which can fulfill their motivation to enjoy pleasing experiences. "Mood management" explains that individuals choose entertainment which provides life balance in feeling pleasure.

Research indicates there is unhealthy behavior by an individual indulging in "binge watching" (Sussman $\&$ Moran, 2013). The habit of high frequency viewing makes a person not engage in exercise, and gives rise to health problems in the form of obesity in an individual. Cousineau, Goldstein, and Franco (as cited in Santrock, 2013) stated that early in youth, the risks from obesity, lack of sleep and an unhealthy lifestyle are increased. This was demonstrated by one of the participants, who was certainly the youngest.

The researchers saw that "binge watching" produced recurrent parasocial interaction. A serial drama with a large number of episodes has similarities to the 
characteristic of "retroactivity" (Madison, Porter, \& Greule, 2016). Repeated parasocial interaction can reinforce the themes seized upon by the viewers and defend interaction with the personas as compensation for the non-occurrence of the hoped for interaction, in reality.

Madison, Porter, and Greule (2016) stated that variation does not influence parasocial characteristics of the function of compensation. People tend to experience a parasocial interactional focus on the character they like. This research indicated that parasocial interaction may also occur with hated characters. A person who does not like a particular real character will also not care for a similar fictional character.

"Binge watching" shares one concept with parasocial characteristics, i.e., frequency. The higher the frequency, the higher the parasocial level. For that reason, the four participants, who had high intensity viewing habits, evinced high parasocial characteristics. This research further clarified the parasocial interaction when viewing Korean dramas, using the concept of the parasocial interaction process put forward by Klimmt, Hartmann, and Schramm (2006). The content of Korean dramas produced parasocial interaction of the same sort as romantic themes. Stever (2011b) stated that "vicarious romance" can fulfill the need for romantic experiences of young women. This research discovered that parasocial interaction produced this "vicarious romance".

The participants made the stories in the Korean dramas their own experiences, which could not possibly occur, and their imaginary visualizations. They were aware that it would be difficult to have these stories take place in the real world, therefore they viewed the dramas. The behavior of the devotees may be tied to the developmental phase of the individual, wherein, in young adulthood, people are faced with developmental duties (Stever, 2011b).

Levinson (as cited in Stever, 2011b) made the argument that transition through the developmental phases may influence parasocial relationships with celebrities. The results of this research also indicated that there were differences in interpretation and focus between the participants who had just commenced tertiary studies, and those about to complete their time at university. Transition towards a new life causes the thinking of people to develop. The researchers noted that this can be something considered by an individual when selecting programmes and celebrity figures for their parasocial interaction.

Kottak (2016) stated that anthropologists define culture as comprising knowledge, beliefs, perceptions, attitudes, values and behavior patterns, learned by people, from their environment. Media broadcasts, which are easily accessed, are environmental examples these days. Therefore, media broadcasts are also able to create culture. Jeong, Lee, and Lee (2017) stated that there is an argument concerning devotees of Korean drama in Indonesia, as a nation, the majority of whose inhabitants are Muslims. The concepts of male Muslims are at variance with those of the males in Korean dramas. This causes a conflict between Muslim females who are devotees of Korean dramas, and their attraction to the males in these dramas, whose attitude is more in accord with that of the minority in Indonesia (Jeong, Lee, \& Lee, 2017).

\section{Limitations and Suggestions for Future Studies}

There were limitations to this research from the viewpoint of the use of the parasocial interaction theory. The guiding composition for the interviews tended to follow the direction from the participants, so that this made possible the bypassing of certain aspects. The participants became aware of their cognitive processes only after receiving "probing" questions, making it possible that there might be additional information from them, which had not previously surfaced in their parasocial interactions. The researchers became aware of the need for more detailed and controlled journal writing procedures, in order to be able to observe actual viewing activities.

The development of technology has made viewing experiences increasingly diverse, so that this may influence the parasocial interaction which occurs. There needs to be further research on broadcasts, for example through particular (advanced) technology such as "virtual reality" (VR), and other image recording. The types of broadcast content are developing rapidly, so the choices of broadcast content can be more specific, based upon the type of story.

\section{Acknowledgements}

The authors thank the Himpunan Psikologi Indonesia (HIMPSI - Indonesian Psychology Association) for conducting the Temu Ilmiah Nasional (National Scientific Meeting), at the Kongres HIMPSI XIV (14th HIMPSI Congress), in Bandung, Central Java, Indonesia. The authors also thank the Kementerian Riset dan Teknologi (Kemenristek - Indonesian Ministry of Research and Technology) for holding the Klinik Penulisan Artikel Ilmiah Nasional (National Scientific Article Writing Clinic) in Solo, Central Java, Indonesia. 


\section{References}

Adam, A., \& Sizemore, B. (2013). Parasocial romance: A social exchange perspective. Interpersona, 7, 1225. https://doi.org/10.5964/ijpr.v7i1.106

Ahmed, A., \& Khalid, M. Z. (2012). Construction of contemporary women in soap opera. Global Media Journal - Indian Edition, 3(1), 1-9.

Bartsch, A., \& Viehoff, R. (2010). The use of media entertainment and emotional gratification. Procedia - Social and Behavioral Sciences, 5, 2247-2255.

Braun, V., \& Clarke, V. (2006). Using thematic analysis in psychology. Qualitative Research in Psychology, 3(2), 77-101. https://doi.org/10.1191/147 8088706qp063oa

Bryant, J., \& Zillmann, D. (2002). Media effects: Advances in theory and research (2nd ed.). New Jersey: Lawrence Erlbaum Associates, Inc.

Brown, W. J. (2015). Examining four processes of audience involvement with media personae: Transportation, parasocial interaction, identification, and worship. Communication Theory, 25, 259-283. https:// doi.org/10.1111/comt.12053

Bolger, N., Davis, A., \& Rafaeli, E. (2003). Diary methods: Capturing life as it is lived. Annual Review of Psychology, 54, 579-616. https://doi.org/10.1146/ annurev.psych.54.101601.145030

Chin, B., \& Morimoto, L. H. (2013). Towards a theory of transcultural fandom. Participations - Journal of Audience and Reception Studies, 10(1), 92108.

Chuang, L. M., \& Lee, H. E. (2013). Korean wave: Enjoyment factors of Korean dramas in the U.S.. International Journal of Intercultural Relations, 37(5), 594-604. https://doi.org/10.1016/j.ijintrel.2013.07.003

Exelmans, L., \& Van den Bulck, J. (2017). Binge viewing, sleep, and the role of pre-sleep arousal. Journal of Clinical Sleep Medicine, 13(8), 1001-1008. https://doi.org/10.5664/jcsm.6704

Geraghty, C., \& Weissmann, E. (2016). Women, soap opera, and new generations of feminists. Critical Studies in Television: The International Journal of Television Studies, 11(3), 365-384. https://doi.org/ $10.1177 / 1749602016661948$

Giles, D. C. (2002). Parasocial interaction: A review of the literature and a model for future research. $\mathrm{Me}$ dia Psychology, 4(3), 279-305. https://doi.org/10. 1207/S1532785XMEP0403_04

Green, M., \& Dill, K. E. (2012). Engaging with stories and characters: Learning, persuasion, and transportation into narrative worlds. In K. E. Dill (Ed.), The Oxford handbook of media psychology. Oxford: Ox- ford University Press. https://doi.org/10.1093/oxford hb/9780195398809.013.0025

Jeong, J-S., Lee, S-H., \& Lee, S-G. (2017). When Indonesians routinely consume Korean pop culture: Revisiting Jakartan fans of the Korean drama Dae Jang Geum. International Journal of Communication, 11, 2288-2307.

Kaun, A. (2010). Open-ended online diaries: Capturing life as it is narrated. International Journal of Qualitative Methods, 9(2), 133-148. https://doi.org/ 10.1177/160940691000900202

Khoiri, A. (March, 2018). Drama Korea punya potensi pasar besar di Indonesia. Retrieved April 20, 2018 from https://www.cnnindonesia.com/hiburan/2018 0317185702-220-283840/drama-korea-punya-pot ensi-pasar-besar-di-indonesia

Klimmt, C., Hartmann, T., \& Schramm, H. (2006). Parasocial interactions and relationships. In J. Bryant \& P. Vorderer (Eds.), Psychology of entertainment (pp. 291-313). Mahwah, NJ: Erlbaum.

Kottak, C. P. (2016). Prime-time society: An anthropological analysis of television and culture, updated edition. New York: Routledge. https://doi.org/ 10.4324/9781315421933

Lather, J., \& Moyer-Guse, E. (2011). How do we react when our favorite characters are taken away? An examination of a temporary parasocial breakup. Mass Communication and Society, 14(2), 196-215. https:// doi.org/10.1080/15205431003668603

Madison, T. P., \& Porter, L. V. (2016). Cognitive and imagery attributes of parasocial relationship. Imagination, Cognition and Personality: Consciousness in Theory, Research, and Clinical Practice, 35(4) 359379. https://doi.org/10.1177/0276236615599340

Madison, T. P., Porter, L. V., \& Greule, A. (2016). Parasocial compensation hypothesis: Predictors of $\mathrm{u}-$ sing parasocial relationships to compensate for reallife interaction. Imagination, cognition and personality: Consciousness in Theory, Research, and Clinical Practice, 35(3), 258-279. https://doi.org/10. 1177/0276236615595232

Patton, M. Q. (2001). Qualitative research and evaluation methods (3rd ed.). Saint Paul, MN: Sage Publications.

Santrock, J. W. (2013). Life-span development (14th ed.). New York: McGraw Hill Companies, Inc.

Stever, G. S. (2011a). Celebrity worship: Critiquing a construct. Journal of Applied Social Psychology, 41(6), 1356-1370. https://doi.org/10.1111/j.15591816.2011.00765.x

Stever, G. S. (2011b). Fan behavior and lifespan development theory: Explaining parasocial and social 
attachment to celebrities. Journal of Adult Development, 18(1), 1-7. https://doi.org/10.1007/s10804010-9100-0

Sussman, S. \& Moran, M., B. (2013). Hidden addiction: Television. Journal of Behavioral Addictions, 2(3), 125-132. https://doi.org/10.1556/JBA.2.201 3.008

Syafrina, D., Permatasari, D. P., \& Dara, Y. P. (2016). Parasosial dan romantic beliefs: Studi pada penon- ton serial drama Korea. Mediapsi, 2(2),16-22. https:// doi.org/10.21776/ub.mps.2016.002.02.3

Tsay-Vogel, M., \& Schwartz, M. L. (2014). Theorizing parasocial interactions based on authenticity: The development of a media figure classification scheme. Psychology of Popular Media Culture, 3(2), 66-78. https://doi.org/10.1037/a0034615

Yin, R. K. (2011). Qualitative research from start to finish. New York: The Guilford Press. 